\title{
Perspectives on Salutogenesis of Scholars Writing in Danish
}

\author{
Vibeke Koushede and Stig Krøger
}

\section{Introduction}

Searching through the Danish literature on salutogenesis, it quickly becomes apparent that this research area has not received much attention in Denmark. There are to date no Danish research environments that stand out in relation to a focus on salutogenesis. A few Danish researchers have conducted studies using a salutogenic perspective, but the research effort appears sparse and uncoordinated. Over time researchers at different universities-primarily at the University of Copenhagen, and at the Danish National Institute of Public Health at the University of Southern Denmarkhave conducted studies examining associations of sense of coherence and physical health, health behaviour, reproductive health, work stress, and sociodemographic factors. The majority of the publications are in English and will therefore not be presented here.

Recently the Danish Healthy Cities Network has established a theme group around mental health. The working foundation for this group is based on a salutogenic perspective (Thybo, 2014). Researchers at the National Institute of Public Health working with mental health promotion are also inspired by this perspective (Koushede, 2014, 2015).

\section{Literature Search}

The literature search was conducted in (1) Danish literature databases; Det Kongelige Bibliotek (The Royal Library), and Den Danske Forskningsdatabase (Danish National Research Database); (2) International databases; PubMed Medline, Embase/PsycInfo, Cinahl, and Web of Science. In all these resources, the truncated term salutogen* (the

V. Koushede $(\bowtie) \cdot$ S. Krøger

National Institute of Public Health, University of Southern Denmark, Odense, Denmark

e-mail: vibe@niph.dk; skan@niph.dk
Danish word for salutogenesis is salutogenese) was used, except in the Danish National Research Database which does not accept truncation. Instead the original term of interest salutogenese was used. Furthermore, sense of coherence was searched as "sense of coherence" in all resources. For all resources, the only limitation set was language $=$ Danish .

Regarding the format of the literature, research articles (print/electronic), books, book chapters, reports, and doctoral theses have been included since the salutogenic model and the concept of salutogenesis are identified within a wide range of literature. Additional quality publications have also been included in order to give the reader a good overview. We have focused on literature where salutogenesis constitutes a central theme or working foundation.

\section{Health Professions and Patient Groups}

The salutogenic perspective has been used as a foundation within various health-related professions. Some of the first work written in Danish stems from the medical profession and emerged from work by Hollnagel and Malterud in the mid-late 1990s (Hollnagel \& Malterud, 1995, 2002). They suggested salutogenesis as a relevant foundation for talking with patients in general practice about risks and health resources. They developed a theoretical model for a patientcentred, salutogenic approach with the aim of a better balance between health resources and risk factors. In their papers, they briefly present results of dialogues in the general practice consultation based on key questions about self-assessed health resources (Hollnagel \& Malterud, 1995, 2002).

For the reader interested in a good introduction and overview of Antonovsky's theory on salutogenesis, this is presented in a popular scientific manner in two articles (Thybo, 2003, 2004) as well as in a Danish research-based 
book on mental health promotion (Koushede, 2015) all aimed at healthcare professionals.

Nielsen presents a salutogenic framework for professionals working with children and adolescents with problem behaviour (Nielsen, 2004). In her PhD thesis on restrictive eating among children with diabetes or overweight Mark (2009) uses a salutogenic health perspective to examine the children's lifeworld.

In the book For mental sundhed-et nyt perspektiv (For mental health - a new perspective), the reader is given an introduction to salutogenesis which is suggested as a relevant underlying theoretical framework for mental health promotion (Koushede, 2015). In Sundhedsfremme $i$ hverdagen (Health promotion in everyday life), the reader is similarly given an introduction to salutogenesis followed by examples on how to work with health promotion using a salutogenic perspective with different population groups (Fredens, Johnson, \& Thybo, 2011).

Thybo has written a comprehensive textbook on neuropedagogy using a salutogenic perspective. The book is aimed at professionals working with individuals with neuropsychological difficulties, and anyone interested in neuropedagogy (Thybo, 2013).

\section{Population Groups}

Danish population studies have examined the distribution of sense of coherence in relation to age, sex, social class, and self-rated health (Due, 1993; Due \& Holstein, 1998). The role of sense of coherence has also been examined in population studies on stress and medicine use (Koushede, 2010).

The research project Den sociale arv og monsterbrydere is based on a salutogenic foundation. In their book the researchers present results from their work related to social inheritance and to those who manage to break negative social patterns. Also they set forward recommendations for policy-makers (Elsborg, Hansen, \& Hansen, 1999).

Interventions using a salutogenic approach have been suggested as a positive way to work with and strengthen children and adolescents with problem behaviour, and to increase their possibilities of participating actively in their social spheres (Nielsen, 2004).

\section{Final Remarks}

The Danish language literature on salutogenesis is limited with a scarcity of quantitative studies. The majority of the few publications presented above use salutogenesis as a theoretical framework from which various professions can work.

Open Access This chapter is distributed under the terms of the Creative Commons Attribution-Noncommercial 2.5 License (http:// creativecommons.org/licenses/by-nc/2.5/) which permits any noncommercial use, distribution, and reproduction in any medium, provided the original author(s) and source are credited.

The images or other third party material in this chapter are included in the work's Creative Commons license, unless indicated otherwise in the credit line; if such material is not included in the work's Creative Commons license and the respective action is not permitted by statutory regulation, users will need to obtain permission from the license holder to duplicate, adapt or reproduce the material.

\section{References}

Due, P. (1993). Livsløb og helbred hos gamle, enlige, fattige kvinder i Danmark. In A. Helset (Ed.), I lyst og $N \phi d$-Livssituasjonen for gamle kvinner med minstepensjon i Danmark, Norge og Sverige. Oslo: Norsk Gerontologisk Institut.

Due, E. P., \& Holstein, B. E. (1998). "Sense of coherence", social class and health in a Danish population study. Ugeskrift for Laeger, 160, 7424-7429.

Elsborg, S., Hansen, T. J., \& Hansen, V. R. (1999). Den sociale arv og mønsterbrydere. København, Danmark: Danmarks pædagogiske institut.

Fredens, K., Johnson, T. J., \& Thybo, P. (2011). Sundhedsfremme $i$ hverdagen -Få mennesker $d u$ møder til at vokse. København, Danmark: Munksgaard.

Hollnagel, H., \& Malterud, K. (1995). Sundhedsbrøken der blev væk. Maanedsskrift for praktisk laegegerning, 73, 693-701.

Hollnagel, H., \& Malterud, K. (2002). Samtaler om risiko og helbredsressourcer i almen praksis. Ugeskrift for Laeger, 164, $5225-5229$.

Koushede, V. (2010). Stress kan fordoble risikoen for at bruge smertestillende medicin. Lagemiddelforskning.

Koushede, V. (2014). Salutogenese. Copenhagen: The Danish National Institute of Public Health. Retrieved from www.si-folkesundhed.dk/ Forskning. Mental sundhed.

Koushede, V. (2015). For mental sundhed-et nyt perspektiv. København, Danmark: Statens Institut for Folkesundhed.

Mark, E. (2009). Restriktiv spisning i narrativ belysning. PhD, Aalborg sygehus, Århus Universitetshospital.

Nielsen, J. (2004). Problemadfard. Børns og unges udfordringer til fallesskabet. København, Danmark: Hans Reitzels Forlag.

Thybo, P. (2003). Sygdom er hvordan man har det: Sundhed er hvordan man ta'r det—om Antonovskys salutogenetiske idé. Kognition \& Padagogik, 49.

Thybo, P. (2004). Sygdom er, hvordan man har det-Sundhed er, hvordan man ta'r det. Klinisk Sygepleje, 3, 4-12.

Thybo, P. (2013). Neuropadagogik-Hjerne, liv og laring. København, Danmark: Hans Reitzels Forlag.

Thybo, P. (2014). Det Dobbelte KRAM-et salutogent arbejdsgrundlag for temagruppen om mental sundhed $i$ Sund By Netvarket. Sund By Netværket. Retrieved from www.sund-by-net. $\mathrm{dk} /$ publikationer. 